\title{
Inclusory pronouns in Mande : The emergence of a typological rarum
}

\section{Khachaturyan, Maria}

2019-04

Khachaturyan, M 2019 , ' Inclusory pronouns in Mande : The emergence of a typological pÿrarum ' , Folia Linguistica , vol. 53 , no. 1 , pp. 87 123 . https://doi.org/10.1515/flin-2019-2005

http://hdl.handle.net/10138/304873

https://doi.org/10.1515/flin-2019-2005

submittedVersion

Downloaded from Helda, University of Helsinki institutional repository.

This is an electronic reprint of the original article.

This reprint may differ from the original in pagination and typographic detail.

Please cite the original version. 


\section{Inclusory pronouns in Mande: \\ The emergence of a typological rarum}

Maria Khachaturyan

Folia Linguistica 2019; 53(1): 87-123

https://doi.org/10.1515/flin-2019-2005

\section{NB: this is a pre-review version, please contact the author for the final version}

\section{Abstract}

This paper reviews inclusory constructions and pronouns in the Mande language family and proposes a diachronic account of their development. Inclusory constructions, which are found in several Mande languages, are a type of conjunction strategy where the whole set of participants - the superset - and a subset of participants are expressed, as in Dan-Gwetaa yāā Gbätö 'Gbato and I', lit. 'we Gbato'. In a number of Southern and Southwestern Mande languages, inclusory constructions are typologically unique, as they feature a separate series of inclusory pronouns, which are used exclusively in this construction. The paper argues that these inclusory pronouns are a Southwestern Mande innovation, which spread to other Mande languages through contact.

Keywords: coordination, comitative, inclusory construction, language contact, typological rara

\section{Introduction}

The inclusory construction, or IC (Lichtenberk 2000, Haspelmath 2004:25-26), is a type of conjunction strategy, along with coordinative and comitative constructions. The crucial property of an IC is that one of its constituents has the same reference as the entire construction. This constituent, the superset, is typically an inclusory pronominal, IP, as in (1) from Dan-Gweetaa.

(1) Dan-Gweetaa, Mande (Vydrin 2010:165)

$\begin{array}{llll}{[y \bar{a} \bar{a}} & \text { Gbätö] } & y a ́ & n \bar{u} . \\ \text { we } & \text { P.N. } & \text { we.AUX } & \text { come }\end{array}$

'Gbato and I, we have come (lit.: we [including] Gbato, we have come)'. 
The example above contains an inclusory construction yāa Gbätö, where Gbätö is a proper name and $y \bar{a} \bar{a}$ 'we' is an inclusory pronoun. The group of participants includes the speaker and a person named Gbato. A proper English translation would, therefore, be 'Gbato and I'. However, only one of the participants, namely, Gbato is overtly specified, while the speaker is implied by the choice of the first person plural pronoun. Unlike in the coordination or comitative strategy, the inclusory pronoun 'we' refers to the whole group of participants. The construction can be literally translated as 'we [including] Gbato'.

ICs are common in Austronesian languages (Lichtenberk 2000, Bril 2004, Lee 2011) and languages from several language families spoken in Australia (Singer 2001). They are also mentioned in Zapotec (Beam de Azcona 2006), Tzotzil (Aissen 1989), some French dialects, some Slavic languages, including Polish and Russian (Tesnière 1951, Schwartz 1985, 1988a, 1988b), and many other languages across the globe (Daniel 2000: 175-176). ICs are also common in the South-West and Southern branches of the Mande family.

In this paper, I will address the ICs in Mande languages in light of a typology of ICs. I will show that the Mande family is typologically unusual, since in several languages of this family IPs form a series distinct from other pronominals.

Inclusory pronouns in Mande were studied by Vydrin (2010), Babaev (2010) and Konoshenko $(2014,2015)$ who used the terms "compound pronouns", "conjunctive pronouns" and "coordinative pronouns", respectively. The present article identifies inclusory constructions in Mande according to their typological profile. It also extends the list of languages featuring inclusory constructions. Finally, it presents a novel hypothesis about the origin of the construction. The paper does not give a detailed account of the semantics of the construction, which varies across Mande languages in minor, but significant details, and which should be object of a future study.

One of the Mande languages included in the study is Mano, the work is based on my own fieldwork data. Some Mano examples are elicited, some come from natural speech marked el. and nat., respectively. Examples from other Mande languages are extracted from the available literature on these languages, and in some cases, from unpublished corpora, courtesy of my colleagues. 
The paper begins with a discussion regarding some key features of Mande languages (Section 2). Section 3 provides an overview of strategies of NP coordination in Mande. Section 4 focuses on inclusory constructions in Mande: it begins with a typological overview (section 4.1) followed by a discussion of languages where inclusory constructions do not feature a dedicated series of inclusory pronouns (Section 4.2). Section 4.3 discusses languages with dedicated series of inclusory pronouns. Finally, in Section 5 I discuss possible origins of inclusory constructions in Mande.

\section{Mande languages: an overview}

The Mande family includes some 50 languages spreading from Gambia to West Nigeria, and from the Central Ivory Coast to the very South of Mauritania. On internal classification of Mande, see Vydrin (2009), for the language map, see Vydrin, Bergman and Benjamin (2000). The major branches of the family are: South-Eastern and Western Mande. The former includes South Mande, and the latter, Central and South-West Mande, which will consequently be discussed in the present paper.

Mande languages are characterized by a fixed S-AUX-O-V-X word order, where AUX is an auxiliary and $\mathrm{X}$ is any postverbal argument or adjunct, including postpositional phrases and adverbs. In the noun phrase, the modifiers generally follow the head.

The majority, if not all, Mande languages are tonal (on tonal marking in this paper, see Table $\mathrm{i}$ in the appendix). They differ, however, in the degree of tonal complexity. They typically have two (Mandinka, Manden branch) to three tonal contrasts, e.g., Mano (South Mande) or Guinean Kpelle (South-West Mande). By contrast, Dan-Gweetaa (South Mande) acquired five tonal contrasts. Languages with more tonal contrasts tend to have a richer tonal morphology (Konoshenko 2014).

South-West and most South Mande languages are unusual if compared to other Mande languages as they have developped rich pronominal paradigms (Vydrin 2006, Babaev 2010). These languages typically have sets of pronominal auxiliaries which have developped from a merger of a pronominal subject marker with a tense, aspect, modality, and polarity marker. The number of pronominal stems employed in these pronominal series is usually much smaller than the number of series. The series are 
distinguished by segmental and/or suprasegmental contrasts. Consider the following triplet from Mano:

(2) Mano, South Mande (own data, el.)

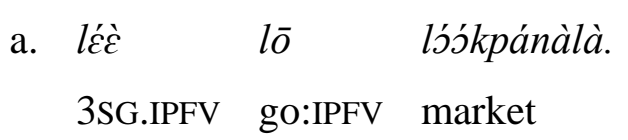

'He goes to the market (habitually).'

b. lèć ló lóśkpánàlà.

3SG.NEG go market

'He does not go to the market (habitually).'

c. le gó-pèlè lóśkpánàlà.

3SG.EXI go-INF market

'He is going to the market.'

(2a) illustrates the imperfective construction. The pronominal auxiliary used in this construction belongs to the imperfective series and has a high-low tonal contour and a long vowel. (2b) illustrates the negative imperfective construction. The negative auxiliary is identical to the imperfective auxiliary on the segmental level, but has a distinctive low-high tonal contour. Finally, (2c) illustrates the progressive construction. The auxiliary used in this construction belongs to the existential series, it has a mid tone and a short vowel.

South and South-West Mande languages distinguish several syntactic series of pronouns. The typical distinctions include: pronouns occurring in most argument positions (direct object, inalienable possessor, or argument of postposition); autonomous pronouns; and possessive pronouns. Kpelle, a South Mande language, provides an example of a rich pronominal inventory. Table ii in the appendix includes most pronominal series available in the language, including the inclusory series.

\section{NP conjunction in Mande}

Mande languages differ in the way they realize a noun phrase conjunction. Many languages have a repertoire of several different constructions. 
Some languages have coordinative conjunctions. Kla-Dan, South Mande, has a construction with a conjunction (ò wò) bàà , where bàà is obligatory, while $\grave{o} \sim w o ̀$ is optional. $\grave{O}$ is a third person plural pronoun of the contrastive series, $6 \grave{a} \grave{a}$ is a conjunction 'and'. Loko (Vydrin and Morozova 2016:449) and Looma (Mischenko 2016:392) also have coordinate constructions formed with a conjunction.

(3) Kla-Dan, South Mande (Makeeva 2012:255)

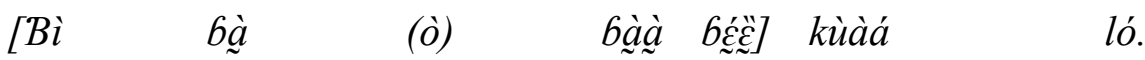

2SG.CNTR 1SG.CNTR 3PL.CNTR and this 1PL.INCL.PROSP go

'You, I, and he (lit.: this one), we are going to leave'.

Zialo and Looma (South-West Mande) have another type of coordinative construction where the coordinative conjunctions are repeated after each conjunct. A similar construction is also attested in Kla-Dan (Makeeva 2012:132) and Loko (Vydrin and Morozova 2016:449).

(4) Looma, South-West Mande (Mishchenko, p.c.)

[Nà wó tá wó] gé vaa-ni.

1SG.CONJ and 3SG.CONJ and 1PL.EXCL.BAS come-AOR

'He and I, we came'

(5) Zialo, South-West Mande (Babaev 2010:25)

[Nà j́j wà jòj] àmó váá-gò.

1SG.FOC and 2PL.FOC and 1PL.INCL.BAS come-AOR

'You (pl.) and I, we came'.

Some Mande languages employ comitative constructions. Thus, Maninka of Kita (Manden) employs an associative construction with a comitative preposition $|n i|$.

(6) Maninka of Kita, Manden (Creissels 2009:141-142)

$N$ dí worì dí [Sékù ní Musa] mà. 
1SG PFV.POS money.DEF give P.N. with P.N. POSTP

'I gave money to Sekou and Moussa.'

Beng (South Mande) employs a construction with both a coordinative conjunction $n \grave{a}$ and a comitative postposition $l \bar{o}$.

(7) Beng, South Mande (Paperno 2014:59)

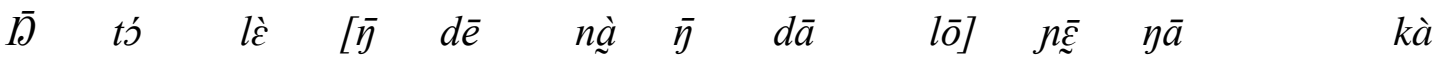

$1 \mathrm{SG}$ name DEF $1 \mathrm{SG}$ father and $1 \mathrm{SG}$ mother with FOC 3PL.PST>3SG put:L $\bar{\varepsilon}$.

FOC

'My name, it was my father and my mother who gave it to me' (literally: 'it was my father and my mother who put it').

Crucially, most of the South-West Mande and some South Mande languages express coordination with inclusory constructions. It may be the only construction available in the language, or one of several available constructions.

\section{Inclusory constructions in Mande}

\subsection{A typological overview}

Inclusory constructions are a type of conjunction strategy (Haspelmath 2004, 2007). Instead of the union of two sets, typical for coordinative and comitative constructions, ICs represent an incorporation of two sets: the whole set of participants, or the superset, and a subset of participants; the latter is semantically included in, but not equal to the former. In South Zapotec, the superset can be expressed by a quantifier (e.g., a numeral, or a construction with a universal quantifier), independently of or together with a pronominal (Beam de Azcona 2006). Haspelmath (2007:34) mentions Margi, a Chadic language, where the inclusory word is a noun with an associative plural marker (Hoffmann 1963). Several other examples with a non-pronominal superset are analyzed in Daniel (2000:178-184). However, an IC typical for Mande languages contains two 
elements: an inclusory pronominal, denoting the superset, and a noun phrase denoting a subset. Consider the following example from Mano:

(8) Mano, own data (el.)

kò Pèé

we P.N.

'Pe and I (lit.: we [including] Pe)'

In the Mano example above, kò 'we' refers to the whole group of participants, which includes the speaker, the person named Pe, and optionally some other participants. Only one participant is overtly specified, the person named Pe. The speaker is presupposed by the choice of the first person plural form of the IP, kò 'we'. Below, I summarize the parameters along which ICs vary cross-linguistically.

\subsubsection{Type of inclusory pronominal}

Lichtenberk (2000) suggests classifying ICs according to the type of IPs found in them. The IP can be a free pronoun (as in 8 above) or a dependent pronominal, i.e. a clitic or a verbal affix (as in 9).

(9) Polish, Indo-European (Schwartz 1988b:52).

$\begin{array}{llll}\text { Poszl-iśmy } & z & \text { matka } & \text { do kina. } \\ \text { went-1PL.NON_F } & \text { with } & \text { mother.INSTR } & \text { to } \\ \text { cinema.GEN }\end{array}$

'Mother and I went to the cinema (lit.: we-went with mother to the cinema).'

In Polish, a subject noun phrase is not obligatory. The person and number of the subject are indexed in the verbal inflection: in the example above, the affix -iśmy indexes the first person non-feminine plural subject. The affix functions as a dependent pronominal of an IC: the subset is expressed by the noun matka 'mother' with a comitative preposition $z$. By contrast, in Mano and in other Mande languages with ICs the inclusory pronominal is free in all except one language, the South Mande language Gban (see example 25). 


\subsubsection{Phrasality of inclusory construction}

Lichtenberk (2000) proposes another parameter which correlates with the preceding one: whether the IC is phrasal or not. Dependent pronominals do not form a contiguous constituent with the NPs of the subset. Such an IC, as illustrated by (9) above, is called split IC (Lichtenberk 2000). By contrast, a free IP and the included NP function as a contiguous constituent and form a phrasal inclusory construction, which is the case of Mande languages with IPs, with the exception of inclusory constructions with subject markers in Gban.

\subsubsection{Specific marking}

Another parameter, according to Lichtenberk (2000), is the presence of a marker indicating the relation between the IP and the NP of the subset. In the absence of such a marker, the construction is of the implicit type; when such a marker is present, the construction is of the explicit type.

Example 10 is a typical example of the implicit type: the inclusory pronominal is expressed by a regular pronoun, there is no specific marking of the construction:

(10) Truku Seediq, Austronesian (Lee 2011:58)

$\begin{array}{lllll}\text { Yami } & \text { Ubus } & k a & m \text {-usa } & \text { me-uyas. } \\ \text { 1PL.EXCL.NOM } & \text { P.N. } & \text { COMP } & \text { AF-go } & \text { AF.FUT-sing }\end{array}$

'I am going to sing with Ubus (lit.: we [including] Ubus are going to sing.'

The inclusory construction in (10) means 'Ubus and I'. It contains only a first person inclusory pronoun yami and a proper name Ubus. By contrast, example 9 from Polish above, as well as example 11 from Chilean Spanish below feature a comitative postposition, which serves as an overt marker of the IC.

(11) Chilean Spanish, Indo-European (Schwartz 1988b: 65)

Fueron al cine con su esposa.

went.3PL to.the cinema with 3.POSS wife 
'He and his wife went to the cinema (lit.: they went to the cinema with his wife).'

Several Mande languages with inclusory constructions are of the explicit type, as they contain a coordinative/comitative element. Consider the following example from KlaDan:

(12) Kla-Dan, South Mande (Makeeva 2012:236)

$\grave{b a ̀ a ̀ ~ G b a ̈ t o ̈ ~}$
1PL.EXCL.CNTR and P.N.
'me and Gbato (lit. we and Gbato)'

Crucially, several Mande languages are typologically unusual as they feature a dedicated series of inclusory pronouns, like in the following example from Mano:

(12) Mano, South Mande (own data, nat.)

$\begin{array}{lll}w \grave{a} & \bar{e} & n \bar{a} \\ \text { 3PL.COORD } & \text { 3SG.REFL } & \text { wife }\end{array}$
'he and his wife (lit.: they [including] his own wife)'

Wà is a pronoun of a special inclusory function (the gloss COORD, coordinative, and not INCL, inclusory, was preferred to avoid confusion with inclusive-exclusive pronouns). The presence of a dedicated pronominal markers makes ICs in these languages explicit. To the best of my knowledge (which was also confirmed by Ruth Singer, p.c.), no other language has a dedicated series of inclusory pronouns, which makes Mande languages unique in this respect.

\subsubsection{Composition of the subsets}

Beam de Azcona (2006) suggests distinguishing between overt and covert subsets. An overt subset is one that is directly indicated by a noun phrase. A covert subset is the remaining one, which is not directly indicated by a noun phrase and which, taken 
together with the overt subsets, adds to the quantity of the superset. In constructions with dual IPs, the exact composition of the covert subset is clear.

(14) Maori, Austonesian (Bauer 1993:368)

maaua ko te rata

1DU.EXCL PREP the doctor

'the two of us, the doctor and I (lit.: the two of us [including] the doctor)'

In the Maori example above, the superset consists of exactly two participants, the doctor and the current speaker. The overt subset being the doctor, the covert subset must be the speaker.

In constructions with plural IPs the quantity of the covert subset is not specified by the construction, but by the context. A typical example comes from Tagalog:

(15) Tagalog, Austronesian (Schachter and Otanes 1972 cited in Haspelmath 2007:33)

sila ni Juan

3PL GEN.ART Juan

'he/they and Juan (lit.: they [including] Juan)'

The overt subset in (15) has one member in it, Juan. The covert subset may consist of one or several members, therefore, there are two interpretations possible, depending on the context: 'he and Juan' or 'they and Juan'.

Often there is a tendency in languages to assign a singular number to the covert subset, although the construction is potentially ambiguous. Thus, in Kpelle the covert subset is by default singular, as in the example below.

(16) Kpelle, Mande (Konoshenko 2014:105)

dà Pépèè

3PL.COORD P.N.

'he and Pepe; not 'they and Pepe' (although lit.: they [including] Pepe)' 
It is only when the overt subset bears plural marking that the covert subset can be plural:

(17) Kpelle, Mande (Konoshenko, p.c.)

[dà hìnáà] dǐ-káá lì-ì lòy̌̌i

3PL.COORD man.PL 3PL-be go-INF forest.in

'He/they and the men (lit.: they [including] the men) are going to the forest.'

In the example above, the overt subset is expressed by a plural noun phrase, hìnáà 'men'. The covert subset can be singular, just like in (16), but this time it can also be plural. Therefore, the inclusory construction in (17) has two possible interpretations: 'he and the men' or 'they and the men'. The exact rules of assignment of number values to covert subsets in Kpelle are unknown.

In some languages, all the subsets can be made overt. In these languages, inclusory pronominals function like a conjunction.

(18) Maori, Austonesian (Bauer 1993:127)

Tuи raatou ko Hine, ko Pau

P.N. 3PL PREP P.N. PREP P.N.

'Tuu, Hine and Pau'

As seen in (14), Maori has inclusory constructions. In the example above, where all the conjuncts are made overt, the function of the inclusory pronoun is similar to that of a conjunction. In some languages, at least one overt subset in the inclusory construction should be expressed by a full NP, like Dan-Gweetaa, Mande (Vydrin, p.c.). Other languages can also conjoin pronominalized noun phrases:

(19) Mano, Mande (own data, el.)

$\begin{array}{lll}m \bar{a} & k \grave{o} & b \bar{\imath} \\ \text { 1SG.EMPH } & \text { 1PL.COORD } & \text { 2SG.EMPH } \\ \text { 'you and I' } & & \end{array}$


Inclusory constructions are attested in two branches of Mande: South-West and South, which are geographically close, but genetically distant (see Section 2). Among SouthWest Mande languages, only Zialo and Looma do not have an IC. In Zialo and Looma, the coordinative strategy is realized by a construction with coordinative conjunctions (see examples 4 and 5). All other South-West Mande languages-namely, Bandi, Mende, Kpelle, and Loko-have an inclusory construction. Inclusory constructions are also attested in five South Mande languages: Mano, Dan-Gweetaa, Guro, Kla-Dan, and Gban. According to the typology presented above, inclusory pronominals in Mande languages are mostly free, and the inclusory constructions are of the phrasal type (with the exception of Gban, see example 25).

In the following two sections, I will review inclusory constructions in Mande in more detail. I will distinguish languages which are more conforming to the known typology, which do not have dedicated series of inclusory pronouns, and the typologically unusual Mande languages which do feature dedicated series of inclusory pronouns. The latter group constitutes the majority of Mande languages with inclusory constructions.

\subsection{Inclusory constructions without dedicated IPs}

Three South Mande languages, Guro, Kla-Dan, and Gban, stand out with respect to other Mande languages analyzed in this paper. First, they do not have a dedicated series of inclusory pronouns (which, by contrast, makes them more conforming to the widespread typological profile). Second, inclusory constructions in these languages contain a comitative or a coordinative element.

\subsubsection{Guro}

In Guro, the function of inclusory pronominals is fulfilled by focalized pronouns. Example 20 illustrates the inclusory construction and example 21 illustrates another function of focalized pronouns, namely the subject of a copula clause. The inclusory construction contains a comitative preposition vàlè.

(20) Guro, South Mande (Konoshenko 2015:74) 


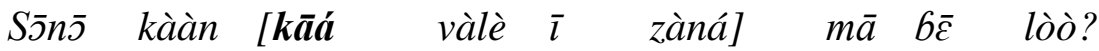

insult NEG 2PL.FOC with 2SG husband on here NEG.Q

'Isn't it an insult to you and your husband (lit.: you (pl.) with your (sg.) husband)'?

(21) Guro, South Mande (Kuznetsova 2013:32)

kāá lé .

2PL.FOC COP

'(Who did this?) You (did).'

\subsubsection{Kla-Dan}

Kla-Dan, just like Guro, does not have a special series of inclusory pronouns. Their function is realized by the contrastive pronouns. The inclusory construction also contains the conjunction 6àà (example 22). Example 23 illustrates the usage of contrastive pronouns with a marker of focus.

(22) Kla-Dan, South Mande (Makeeva 2012:235)

$k a$

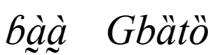

2PL.CNTR and P.N.

'you (sg.) and Gbato (lit.: you (pl.) [including] Gbato)'

(23) Kla-Dan, South Mande (Makeeva 2012:132)

Wò l⿳亠丷厂 $\quad$ wó köj̈ lj.

3PL.CNTR FOC 3PL.JNT calabash buy.JNT

'It was them who bought the calabash.'

\subsubsection{Gban}

Gban has only one series of personal pronouns. This series can be used in the inclusory function. Unlike inclusory constructions in other Mande languages, the pronoun in the inclusory function is situated at the right edge of the inclusory construction, following the NP of the overt subset. The inclusory construction also contains the postposition $f_{\varepsilon}^{\prime \prime}$ 
'with'. Examples 24a and 24b contrast the usage of personal pronouns in inclusory and non-inclusory functions.

(24) Gban, South Mande

a. (Fedotov 2016:991)

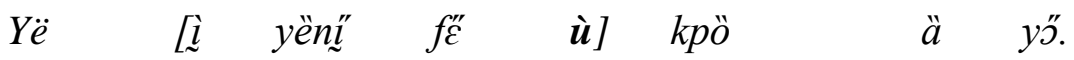

3SG.PST 1SG brother POSTP 1PL call.PFV.HOD 3SG at

'He invited me and my brother (lit. : with my brother, us)'.

b. (Fedotov, p.c.)

Ÿ̈ ù kpö $\quad \ddot{a} \quad y \ddot{~}$

3SG.PST 1PL call.PFV.HOD 3SG at

'He invited us'.

In Gban, the auxiliary includes a personal index and inflects for several grammatical categories, including tense/aspect and mood/polarity. Its internal structure is transparent, as opposed to the pronominal auxiliaries in languages like Mano (2). In contrast with other Mande languages, in Gban the auxiliary can also serve as an inclusory pronominal:

(25) Gban, South Mande (Fedotov 2013:91)

\begin{tabular}{|c|c|c|c|}
\hline$a \quad f \varepsilon$ & àà-kë & $y a ̈$ & $k e=\varepsilon$ \\
\hline POSTP & 2PL-COND.POS & leave:IPFV & $\mathrm{RECP}=\mathrm{on}$ \\
\hline
\end{tabular}

'if you (sg.) and him go to court (lit.: if with him you (pl.) go to the court)...' [Matthew $5: 25]$

The personal index in (25) is part of the verb phrase and functions in a similar way to person and number affixes in pro-drop languages with obligatory agreement with the subject, like Chilean Spanish (11) or Polish verbs (9), as argued by Hachaturyan (2010). Just like Chilean Spanish or Polish examples, (25) illustrates a split inclusory construction with a dependent pronominal, which is the only example of such construction in Mande. 


\subsection{Inclusory constructions with separate series of IPs}

Six out of the nine Mande languages which feature an inclusory construction have a special series of inclusory pronominals.

All South-West Mande which have an inclusory construction also have a dedicated series of inclusory pronouns. These languages are: Kpelle, Mende, Bandi, and Loko.

\subsubsection{Kpelle}

Example 26 illustrates the inclusory construction in Kpelle.

(26) Kpelle, South-West Mande (Konoshenko 2016:335)

\section{kà Pépèè}

2PL.COORD P.N.

'Pepe and you (sg.) (lit.: you (pl.) [including] Pepe)'

The inclusory construction kà Pépèè is composed of a second person plural inclusory pronoun kà and a proper name Pépèè. Inclusory pronouns in Kpelle are represented by a special series. Compare 26 with 27 with a second person plural pronoun of the autonomous series ( $k a ́ a ́)$ and a second person plural auxiliary of the habitual series $(k a \check{a})$.

(27) Kpelle, South-West Mande (Konoshenko 2016:340)

Káá-i à kpغ̀ेè̀े-yàà kă pélí kùlǒ-ì hwóló mù.

2PL.AUT-ART with Kpelle-PL 2PL.HAB can leave-INF sun under

'You (who are) Kpelle, you can go out in the sun [but we, Europeans, we cannot].'

\subsubsection{Mende, Bandi, Loko}

Examples 28, 29 and 30 illustrate inclusory constructions in Mende, Bandi, and Loko, which function in a similar way to Kpelle.

(28) Mende, South-West Mande (Innes 1967:69)

mùá wùé=nì

1PL.COORD 2PL.COM=PL 
'You (pl.) and I (lit.: we [including] you (pl.))'

(29) Bandi, South-West Mande (Babaev 2010:12)

nàá tiyé $=n i$

1PL.EXCL.COORD 3PL.COM=PL

'me and them' (lit. 'we [excluding the addressee, and including] them')

The examples 28 and 29 contain a clitic $=n i$ which is a marker of associative plurality. Its function within the inclusory construction is not a straightforward one, and will not be discussed in the present paper. In both examples, the overt subset is expressed by a pronoun of a comitative series (COM). I will go back to the discussion of this pronoun in Section 5.1.

(30) Loko, South-West Mande (Vydrin and Morozova 2016:449)

mes bia-o

1PL.INCL.COORD 2SG.AUT-ASSOC

'Me and you (lit.: we [including] you)'

Table 1 summarizes inclusory pronouns in South-West Mande.

Table 1: Inclusory pronouns in South-West Mande

\begin{tabular}{|c|c|c|c|c|c|}
\hline & 1PL.INCL & 1PL.EXCL & 2PL & 3PL & \\
\hline Kpelle & $g w \grave{a}$ & $k w a ̀ ~$ & $k \grave{a}$ & $d \grave{a}$ & (Konoshenko 2016) \\
\hline Mende & \multicolumn{2}{|c|}{ mùá màá } & wùá wàá & tìá tàá & (Migeod 1908; Innes 1967) \\
\hline Bandi & màá má & nàá ná & wá(á) & tà $(a ́)$ & (Babaev 2010) \\
\hline Loko & $m \varepsilon \varepsilon$ & $n \varepsilon \varepsilon$ & $w \varepsilon \varepsilon$ & $t \varepsilon \varepsilon$ & (Vydrin and Morozova 2016) \\
\hline
\end{tabular}

\subsubsection{Mano}

Dedicated inclusory pronouns are attested in two South Mande languages: DanGweetaa and Mano. The following example illustrates the inclusory construction in Mano. 
(31) Mano, South Mande (own data, nat.)

wà lòóò

3PL.COORD 3SG.REFL mother

'he and his mother (lit.: they [including] his own mother)'

\subsubsection{Dan-Gweetaa}

Dan-Gweetaa has three series of inclusory pronouns: a simple series, a series fused with the third person non-subject pronoun $\ddot{a}$, and a portmanteau series. The latter series is used when both conjuncts are pronominalized, and functions more like a compound pronoun (Hyman 1979), than an inclusory pronoun. It will not be discussed in this paper, as a detailed description of its functioning can be found in (Vydrin 2010).

Simple inclusory pronouns have two tonal variants, one with level mid tone, and another with mid-extra low tonal contour. Thus, the first person simple inclusory pronoun has two forms, $y \bar{a} \bar{a}$ and $y \bar{a} \ddot{a}$. The mid-extra low tonal variant of the simple pronouns, and only this variant, can also be used when the pronoun is merged with the third person singular non-subject pronoun $\ddot{a}$. Example 32 below illustrates the distinction between simple and fused inclusory pronouns:

(32) Dan-Gweetaa, South Mande (Vydrin 2010:165-166)
a. $\quad$ YYā̄ā $\sim \boldsymbol{y} \bar{a} a ̀$
Gbätö] yá
$n \bar{u}$.
1PL.COORD P.N. 1PL.EXCL.PRF come

'Gbato and I, we have come (lit.: we [including] Gbato, we have come)'.

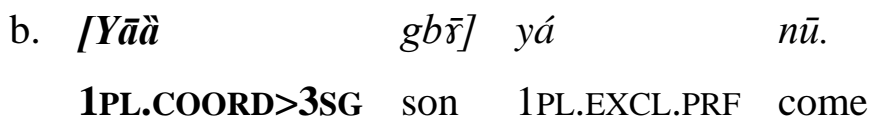

'Me and his son, we came (lit.: we [including] his son, we came).'

Table 2 summarizes inclusory pronouns in South Mande. 
Table 2: Inclusory pronouns in South Mande

\begin{tabular}{|c|c|c|c|c|c|c|}
\hline & & PL.INCL & 1PL.EXCL & $2 \mathrm{PL}$ & $3 P L$ & \\
\hline Mano & & kò & & kà & $w a ̀ ~$ & own data \\
\hline \multirow[t]{2}{*}{ Dan-Gweetaa } & simple & $k w \bar{a} \bar{a} \sim k w \bar{a} a \ddot{a}$ & $y \bar{a} \bar{a} \sim y \bar{a} a ̈$ & $k \bar{a} \bar{a} \sim k \bar{a} a ̈$ & $w \bar{a} \bar{a} \sim w \bar{a} a ̈$ & (Vydrin 2010) \\
\hline & fused & $k w \bar{a} a ̈$ & $y \bar{a} a \ddot{~}$ & $k \bar{a} a \ddot{~}$ & $w \bar{a} a ̈$ & \\
\hline
\end{tabular}

\section{Origins of the inclusory pronouns and constructions in Mande}

As we saw in the previous section, nine Mande languages developed an inclusory construction. This construction is not in itself a typological rarity. What deserves a special attention is the fact that in six Mande languages belonging to two genetically distant groups, South-West and South Mande, appeared dedicated series of inclusory pronouns, a phenomenon which has not been attested outside the Mande language family. Other three Mande languages with inclusory construction belong to the South Mande group and do not have dedicated inclusory pronouns. The rest of South-West and South Mande do not have an inclusory construction. Figure 1 represents South and South-West Mande languages with and without inclusory constructions.

Figure 1: Inclusory construction in Mande

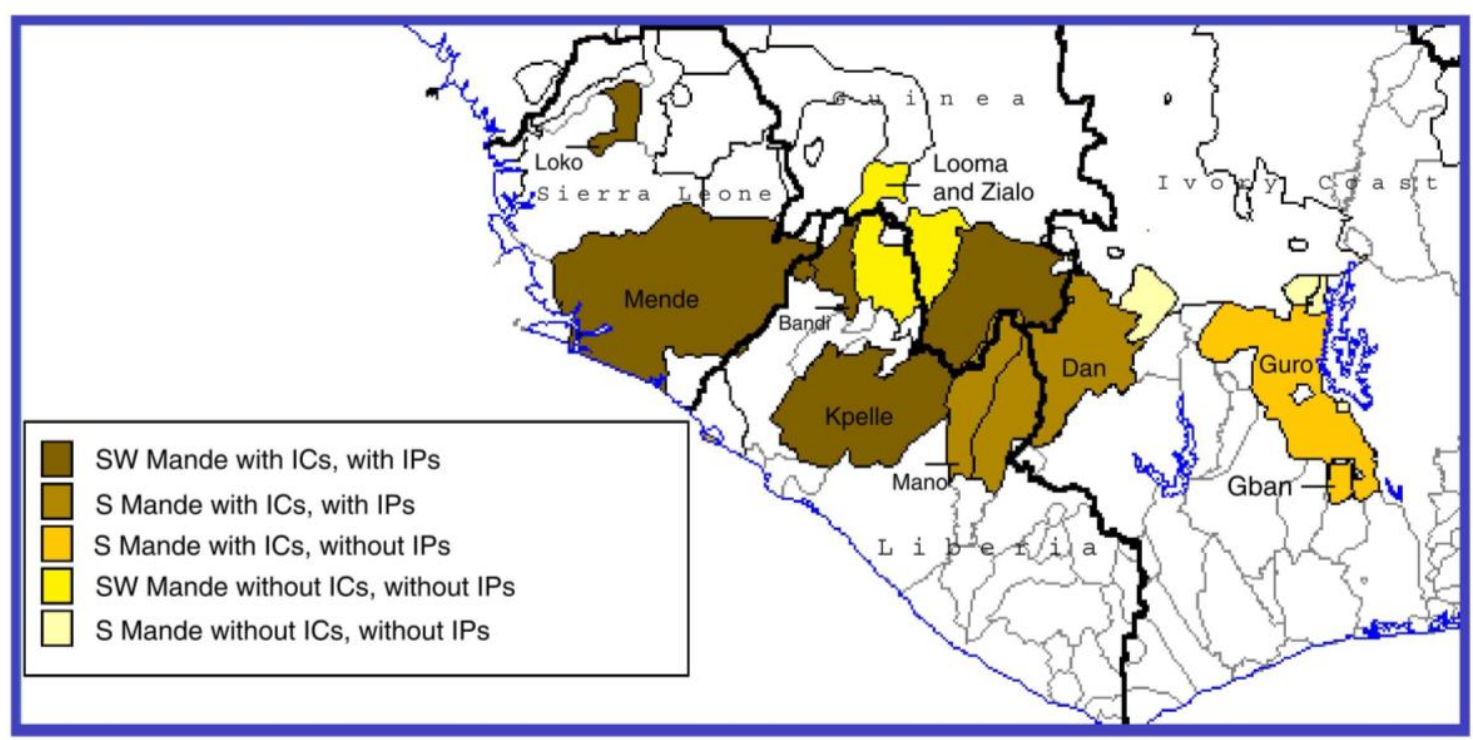

In this section, I will give a tentative explanation of the origins of inclusory constructions and pronouns in Mande. 


\subsection{South-West Mande}

Let us recall that four out of six South-West Mande languages have dedicated inclusory series which are fairly close phonologically (see Table 1). The inclusory series could therefore be considered an innovation at the Proto-South-West level, as suggested by Babaev (2010). According to this hypothesis, the series was inherited in Kpelle, Bandi, Mende, and Loko, and was lost in Zialo and Looma. The Table 3 presents Babaev's tentative reconstruction of the protoform of the inclusory pronouns.

Table 3: Inclusory pronouns in proto-South-West Mande (Babaev 2010:45)

$$
\begin{array}{lll}
\text { 1PL } & 2 \mathrm{PL} & 3 \mathrm{PL} \\
\text { *mà } & \text { *wá } & \text { *tà }
\end{array}
$$

In what follows, I will suggest a novel diachronic scenario. Specifically, I will argue that prior to the series of inclusory pronouns emerged an inclusory construction containing a pronoun in the inclusory function and a comitative preposition.

This construction was the source of the lexicalization of the inclusory pronouns in proto-South-West Mande, which may have very well been the series suggested by Babaev. The composition of the construction that I suggest is the following: a pronoun in the inclusory function, followed by a comitative preposition, followed by a noun phrase representing the overt subset:

Stage 0 in the development of inclusory pronouns in proto-SWM

$$
\text { Pron - [Prep - NP] }
$$

This construction was subsequently reanalyzed in a way that the pronoun in the inclusory function formed a closer tie with the comitative preposition:

Stage 1 in the development of inclusory pronouns in proto-SWM

$$
\text { [Pron - Prep] - NP }
$$


The last step was a fusion between the pronoun in the inclusory function and the comitative preposition, which gave rise to the dedicated series of inclusory pronouns:

Stage 2 in the development of inclusory pronouns in proto-SWM

$$
\text { [Pron.INCL] - NP }
$$

My argument will have the following structure. I will begin by reviewing typological evidence which validates the hypothesis about the internal structure of the inclusory construction in proto-South-West Mande and its subsequent fusion. I will then show that lexical material from which the construction could be composed may indeed be reconstructed at the proto-level of the group. Then I will argue that the fusion could indeed have taken place, as such a process is common in South-West Mande. Finally, I will consider an alternative hypothesis.

\subsubsection{Typological evidence}

Comitative adpositions are frequently used for NP conjunction (Arkhipov 2009). This is a common pattern in Mande, see example 6 from Maninka, Manden and 7 from Beng, South Mande. Inclusory constructions across languages sometimes contain comitative adpositions: we saw examples from Polish (9) and Chilean Spanish (11), comitative adpositions also occur in Niuean, Austronesian (Lichtenberk 2000:4). The South Mande language Guro (20), features inclusory constructions containing a comitative adposition; the postposition used in the inclusory construction in Gban (24a) is very likely of comitative origin, as well (Fedotov, p.c.).

There exists a typological parallel to the lexicalization of inclusory pronouns from a combination of a pronoun with a comitative element, namely, compound pronouns in Bantoid languages. In Aghem (Hyman 1979), a comitative construction, containing the comitative conjunction/preposition à, is used anytime pronominal elements are conjoined.

(33) Aghem, Bantoid (Hyman 1979:53)

ghé à mùs 
3PL with $1 \mathrm{SG}$

'they and me'

The example above features two separate conjuncts: a third person plural, ghé, and a first person singular, mùs. Examples like 33 are regular, cumulative combinations of pronouns. Compound pronouns, lexicalized from comitative constructions, arise when such combinations are fused morphophonetically:

(34) Aghem, Bantoid (Hyman 1979:53)

ghà?à ghé

1PL $>$ with 3PL

'me and them', 'us and him', or 'us and them'

Compound pronouns function in a similar way to inclusory pronouns. In (34), the compound pronoun ghà̀à indexes an "incorporative bond" (Hyman 1979:53). The whole construction means "us, including him/her/them" (there are other interpretations available). In contrast with inclusory pronouns, compound pronouns cannot be used in constructions with full NPs. Another distinctive feature of compound pronouns is that their meaning can be non-compositional. Crucially, compound pronouns like ghà?à arise from the fusion of a pronominal element with a comitative conjunction/preposition, the construction that could be at the origin of the inclusory pronouns in South-West Mande.

\subsubsection{Lexical material}

In this section, I will discuss the lexical elements that could be used in the protoinclusory construction. I will first discuss the pronoun used in the inclusory function and then the comitative element.

In Guro and Kla-Dan, two of the three Mande languages which have the inclusory construction, but do not have a dedicated series of inclusory pronouns, the inclusory construction is composed of a pronoun, a comitative (Guro) or coordinative element (Kla-Dan), and the NP of the overt subset. The inclusory constructions in Guro and KlaDan follow the same model I am suggesting for the proto-language of the South-West 
group. The inclusory function is realized by a pronoun of the "focalized" (Guro) or "contrastive" series (Kla-Dan). The focalized pronouns in Guro are also used with copulas (21), while the contrastive pronouns in Kla-Dan are also used with focus markers (23) and as conjuncts in NP coordination (3). It is likely, therefore, that it was a pronoun with a similar function that was used in the inclusory construction in the protolanguage of South-West Mande group. In Kpelle, a South-West Mande language, all three functions, subject of a copula sentence, focus marker and conjunct in NP conjunction, are realized by the pronouns of the same "autonomous" series:

(35) Kpelle, South-West Mande

a. (Konoshenko 2016:325)

Gbèĉé bè? Náá bè.

who FOC come:H 1sG.AUT COP

'Who came?' — 'Me'.

b. (Konoshenko 2016:337)

Náá bé yó $\quad$ biì ká tií.
1SG.AUT FOC 1SG.POSS bag COP that
'This bag is MINE'.

c. (Konoshenko 2016:314)

Hwě gè; $\quad$ náá gwà yé bé tí

3SG.BASE.NEG 3SG.do:H 1SG.AUT 1PL.INCL 2SG.AUT FOC field

$k \grave{\varepsilon}$.

do:

'It was not him - me and you, we worked the field.'

Babaev (2010) suggested a reconstruction of the proto-South-West Mande pronominal system: the proto-series of "focalized" pronouns containing the affix $*_{-y a}$ are the predecessors of autonomous pronouns in Kpelle (see Table 4). I suggest that the same 
series could also be used in the inclusory construction, be it with or without the affix. Even if it was not the focalized series itself, it seems that the reconstruction of the pronouns used in the inclusory function in the proto-language of the South-West group is relatively unproblematic, since the plural forms of the pronouns are remarkably similar across the reconstructed series ${ }^{1}$.

Table 4: Plural pronouns in Proto-South-West Mande (from Babaev 2010)

\begin{tabular}{|c|c|c|}
\hline & $1 \mathrm{PL}$ & 2PL \\
\hline Basic & *mù & *wó \\
\hline Polyfunctional & *mù- & *wó- \\
\hline Inclusory & *mà & *wá \\
\hline Comitative/Instrumental & *mùyè & *wóyè \\
\hline Focalised & *mùyà & *wóyá \\
\hline Possessive & *mù- & *wó- \\
\hline Imperfective & *màà & *wáà \\
\hline Dependent & *mù & *wó \\
\hline Negative & *mù̀̀̀́ & *wóćc̀ \\
\hline Imperative & *mù (du.) *kàmù (pl.) & *kà \\
\hline
\end{tabular}

There exist comitative prepositions in all six South-West Mande languages which are very likely reflexes of the same proto-form. It is this proto-form that could be part of the proto-inclusory construction, from which the inclusory series in proto-South-West Mande developped. These prepositions are given in Table 5 and are contrasted with the inclusory pronouns in languages that have them. Note that in all the languages except Loko the vowel in the pronouns is a short or a long /a/, just like in the preposition. In Loko and Kpelle vowel length in the preposition and in the pronouns match precisely. In Bandi, where the preposition has a long vowel, the pronouns have two variants with a

1 The origin of $* k$ - forms of first and second person plural pronouns in Kpelle, in contrast with the pronouns of the first and second person in other South-West Mande languages, is discussed in Babaev (2010:34-35). 
short and a long vowel. Finally, in Mende, where the preposition has a short vowel, the pronoun has a variant with a long vowel and a diphtong with a short /a/ vowel. In sum, there is a relatively good match between the vowel length in the pronoun and in the preposition.

Table 5: Comitative prepositions in South-West Mande (Babaev 2010)

$\begin{array}{lll}\text { language } & \text { preposition } & \begin{array}{l}\text { 3PL } \\ \text { inclusory } \\ \text { pronoun }\end{array} \\ \text { Kpelle } & \text { à } & \text { dà } \\ \text { Looma } & \text { gà } & \text { N/A } \\ \text { Bandi } & \text { ygáà } & \text { tà(á) } \\ \text { Zialo } & \text { gà } & \text { N/A } \\ \text { Mende } & \text { à } & \text { tìá tàá } \\ \text { Loko } & \text { ygàà àà } & \text { tec }\end{array}$

Note that in present-day South-West Mande languages comitative prepositions are used only to form postpositional phrases which are situated in the postverbal position, as in the following example from Loko. They are never used in inclusory constructions or elsewhere inside NPs:

(36) Loko, South-West Mande (Vydrin and Morozova 2016:443)

$\begin{array}{llll}K K^{\prime} \varepsilon ́ & b a ́-a ́ & a ̀ a ̀ & (\eta-) k a ́ i . \\ \text { AOR.3SG.BAS } & \text { come-PRF } & \text { with } & \text { REF-hoe }\end{array}$

'He came with a hoe', 'He brought a hoe'.

This fact can be accounted for if we assume that, at the proto-level of the group, the prepositions were used in the inclusory construction, but when they merged with inclusory pronouns to form a dedicated inclusory series they lost their independent status. 
The argument supporting the hypothesis that these prepositions were used in the proto-construction, besides their phonological form, is the following. It was briefly noted in section 4.3.2 that in the inclusory construction in Mende and Bandi the pronominalized NP of the overt subset is expressed by a series of so-called comitative pronouns. Crucially, the same series is used with the comitative preposition ygáà 'with'. It is the only context where these pronouns are used outside the inclusory construction. Compare (37), where a comitative pronoun is used with the comitative preposition, with (29) repeated below as (38), where a comitative pronoun is used in the inclusory construction:

(37) Bandi, South-West Mande (Babaev 2010:12)

Dgàlà ndó-ygó lè ygáà íyé.

REF.god love-QUAL COP with 2SG.COM

'God loves you.'

(38) Bandi, South-West Mande (Babaev 2010:12)

nàá

$$
\text { tiyé }=n i
$$

1PL.EXCL.COORD 3PL.COM=PL

'me and them' (lit. 'we [excluding the addressee, and including] them')

If historically the construction contained a comitative preposition, then the distribution of comitative pronouns can be accounted for by a simple rule: comitative pronouns occur with the comitative preposition, be it in a prepositional phrase or inside an inclusory construction.

A similar pronominal series, used only with the comitative preposition and to express the pronominalized subset in the inclusory construction, is found in Mende. In Loko, a special series is also used with the comitative preposition, but not in the inclusory construction, where the autonomous series is used. Looma and Zialo, which do not have an inclusory construction, do have a dedicated series of pronouns used with the comitative preposition. Kpelle is the only language which does not have a comitative series. Table 6 summarizes the presence of comitative series and inclusory constructions 
in South-West Mande. The comitative series can be reconstructed in proto-South-West Mande and is indeed included into Babaev's reconstruction (see Table 4). ${ }^{2}$

Table 6: Comitative series in South-West Mande

\begin{tabular}{l|ccc} 
& \multicolumn{4}{|c}{ comitative series } \\
& IC & in PP & in IC \\
\hline Kpelle & + & - & - \\
Looma & - & + & - \\
Bandi & + & + & + \\
Zialo & - & + & - \\
Mende & + & + & + \\
Loko & + & + & -
\end{tabular}

To sum up, it can be safely argued that inclusory pronouns were present in proto-SouthWest Mande. Moreover, since in Bandi and Mende comitative pronouns are used in the inclusory construction, and since comitative prepositions and pronouns can also be reconstructed at the proto-South-West Mande level, it is likely that a prior inclusory construction contained a pronoun in inclusory function (possibly, of the focalized series), the comitative preposition and (presumably) a comitative pronoun.

\subsubsection{Pronominal fusion in South-West Mande}

Inclusory pronouns would not be the only case in South-West Mande where a specific pronominal series developed out of the fusion of a pronominal element with another element. This process is remarkably common in these languages which have rich

\footnotetext{
${ }^{2}$ As it can be seen in Figure 1, South-Mande languages do not form a continuous zone. The patterns of shared innovations and retentions are not straightforward: as we can see in Table 6 , the retention of the comitative series does not always go together with the retention of the inclusory construction. However, there are two language clusters with similar behavior: Looma and Zialo, on one hand, and Bandi and Mende, on the other hand. Zialo is in close contact with Looma and is a minority language, very likely under a strong influence of Zialo and shares with it many features, including, for example, the coordinative construction (see examples 4 and 5). It is not surprising that the inclusory construction was lost in both these languages. As for Bandi and Mende, they are barely in contact, but they are close both geographically and genetically.
} 
inventories of pronominal elements: auxiliaries and pronouns. Kpelle, for instance, features a series of pronominal elements that emerged as the fusion of pronominal indices with the postposition $6 \grave{a}$ 'on' (Konoshenko 2016:330). In Loko, two pronominal series emerged out of the merger with the postpositions mbé (benefactive series) and mbá (superessive series, Vydrin and Morozova 2016:445). An exemplary paradigm of pronominal markers in Kpelle is given in Table ii of the appendix.

\subsubsection{Alternative hypothesis}

An alternative hypothesis could be that inclusory pronouns in South-West Mande did not appear at the proto-level, but rather lexicalized more recently, in each language of the group independently, from similar lexical material (a pronoun plus a comitative/coordinative element), whence the similarity in their phonological form. If this hypothesis is correct, one would expect to find traces of this construction. In other words, one would expect to find inclusory constructions with a comitative/coordinative element, or at least cases where a comitative/coordinative element is used for NP conjunction. However, as noted above, comitative prepositions are never used NPinternally in present day South-West Mande languages. Coordinative conjunctions occur in Zialo and Looma, but they follow each conjunct and/or the last conjunct. Had they taken part of a prior inclusory construction, we would have expected to find traces of the second part of the conjunction, following the NP expressing the overt subset. This, however, is not observed, which makes Looma and Zialo conjunctions unlikely members of a prior inclusory construction. Therefore, this hypothesis is less plausible.

\subsection{South Mande}

While five South Mande languages feature inclusory constructions, only two of them, Mano and Dan-Gweetaa, have dedicated series of inclusory pronouns.

The least probable origin of these dedicated series of pronouns is that they emerged independently, without having, as a predecessor, a construction with a pronoun in the inclusory function and a comitative or a coordinative element. Such cases have never been attested crosslinguistically, and I have argued that South-West Mande languages are not the case, either. It is also unlikely that in Mano and Dan-Gweetaa, the inclusory 
pronouns grammaticalized from such a construction. In both Mano and Dan-Gweetaa, comitative adpositions are postposed to the noun. Therefore, had they taken part of the inclusory construction, they would not have been adjacent to the pronoun in the inclusory function and could not have contributed to the lexicalization of inclusory pronouns. Moreover, Mano does not have any conjunction coordinating NPs. In DanGweetaa the coordinative conjunctions ... $d^{\prime} \gamma^{\prime} \ldots d \gamma^{\prime}$ and $\ldots \bar{o} \bar{o} \ldots \bar{o} \bar{o}$ follow each conjunct and, again, are unlikely to have participated in the development of inclusory pronouns (see the discussion of a similar problem in Zialo and Looma in the previous section). Therefore, it is unlikely that inclusory pronominals in Mano and Dan-Gweetaa appeared as a result of internal development.

Vydrin (2010) suggests an alternative hypothesis: these series could have emerged under areal influence, more specifically, under the influence of Kpelle. Indeed, there is a strong argument in favor of this hypothesis, especially for Mano. Mano has long been in intense contact with Kpelle, see the present-day language map in Figure $1^{3}$. In Guinea, the region that I am mostly familiar with, many Mano are bilingual with Kpelle, especially in the contact zone, there is a lot of intermarriage. Kpelle speakers outnumber Mano: there are more than 1,200,000 speakers of Kpelle (Konoshenko 2016:284) against 400,000 of Mano (according to Ethnologue). Kpelle may also have a slightly higher social status: Kpelle are more numerous in local administration and in clergy, especially in the Catholic communities. There are many other contact phenomena attested at least in the Mano language at the level of the grammar and vocabulary.

In case of Dan-Gweetaa, it is more difficult to argue in favor of the Kpelle influence on the basis of the sociolinguistic situation. Although the languages of the Dan language cluster have been in close contact with Kpelle and the intermarriage is still common (Vydrin p.c.), the contact has somewhat weakened because of the administrative border: Dan is spoken in Ivory Coast, while Kpelle is spoken in Guinea. Moreover, the DanGweetaa variety is not in immediate contact with Kpelle. However, little is known about the Dan varieties which are in immediate contact with Kpelle, in particular, whether they have inclusory constructions and dedicated series of inclusory pronouns: if they happened not to have inclusory constructions, it would be a counter-evidence to the

\footnotetext{
${ }^{3}$ See also the language map from Ethnologue: https://www.ethnologue.com/language/mev/map.
} 
contact hypothesis. Although the Kpelle influence on Dan-Gweetaa is not certain, it is at least clear that South Mande languages which are not in contact with Kpelle did not develop dedicated series of inclusory pronouns. In particular, Kla-Dan, Guro and Gban have inclusory constructions, but do not have dedicated inclusory pronouns, and neither of these languages is in contact with Kpelle (see Figure 1), which, again, speaks in favor the hypothesis of external influence. Therefore, there is some sociolinguistic evidence in favor of the contact hypothesis as the origin of the inclusory construction in DanGweetaa and none against it. In what follows, I will present structural evidence in favor of the contact hypothesis.

Inclusory constructions in Kpelle, Mano and Dan-Gweetaa are structurally parallel. Consider the following examples:

(39) Mano, South Mande (own data, nat.)

wà Mèlé

3PL.COORD P.N.

'he and Mary (lit.: they [including] Mary'

(40) Dan-Gweetaa, South Mande (Vydrin 2010:165)

yāä Gbätö

1PL.COORD P.N.

'Gbato and I (lit.: us [including] Gbato'

(41) Kpelle, South-West Mande (Konoshenko 2015:75)

wà Pépè̀

3PL.COORD P.N.

'he and Pepe (lit.: they [including] Pepe'

This structural similarity suggests that the emergence of inclusory construction in Mano and Dan-Gweetaa under the influence of Kpelle could have proceeded through metatypy, "syntactic and semantic reordering of a replica language, morph-by-morph" 
(Drinka 2017:13), based in our case on a pattern from Kpelle which acts as the model language.

I argued that the dedicated inclusory pronouns appeared in South-West Mande at the proto-level, therefore, it is likely that Mano and Dan entered in contact with Kpelle at the moment when the inclusory pronouns already lexicalized in the language, leaving no trace of the prior construction with a non-dedicated inclusory pronoun and a comitative preposition. Therefore, it is unlikely that Mano and Dan-Gweetaa replicated the prior construction. Also, as noted above, these two languages do not have the necessary lexical material to replicate it.

Thus, the model construction for Mano and Dan-Gweetaa already contained the dedicated inclusory series. Crucially, in the case of metatypy, the target language uses already available lexical material. As noted above, it is unlikely that the dedicated series of inclusory pronouns in Mano and Dan-Gweetaa arose independently. The only possibility left if that these pronouns were borrowed from Kpelle. Although pronominal borrowing is relatively rare across languages (see a discussion in Thomason 2001:8384), note the remarkable similarity in the form of the pronouns in Mano, Dan-Gweetaa, and Kpelle, especially between Mano and Kpelle (see Table 7), modulo the initial consonants of the pronouns, which are usually uniform in the plural forms across pronominal series in each of the language in question (see Table ii in the Appendix for a detailed account of the pronominal system in Kpelle).

Table 7: Inclusory pronouns in Kpelle, Mano and Dan-Gweetaa

\begin{tabular}{|c|c|c|c|c|c|}
\hline & & 1PL.INCL & 1PL.EXCL & $2 \mathrm{PL}$ & 3PL \\
\hline Kpelle & & gwà & $k w \grave{a}$ & $k a ̀$ & $d \grave{a}$ \\
\hline Mano & & $k \grave{o}$ & & $k a ̀$ & wà \\
\hline \multirow[t]{2}{*}{ Dan-Gweetaa } & simple & $k w \bar{a} \bar{a} \sim k w \bar{a} \ddot{a}$ & $y \bar{a} \bar{a} \sim y \bar{a} a \ddot{a}$ & $k \bar{a} \bar{a} \sim k \bar{a} a \ddot{a}$ & $w \bar{a} \bar{a} \sim w \bar{a} a \ddot{a}$ \\
\hline & fused & $k w \bar{a} a ̈$ & yāä & $k \bar{a} a ̈$ & $w \bar{a} a ̈$ \\
\hline
\end{tabular}

Three other South Mande languages, Guro, Kla-Dan and Gban, have an inclusory construction, but do not have a separate series of inclusory pronominals. Note that in all 
three languages the structure of the construction is different from Dan-Gweetaa and Mano, on one hand, and from South-West Mande, on the other: they all contain a comitative/coordinative element. In Gban, moreover, the inclusory pronouns follow the noun phrase of the overt subset and do not precede it, as in all other Mande languages. Although Gban and Guro are in contact (see Figure 1), it is unlikely that they influenced each other in the grammaticalization of inclusory constructions. Therefore, these languages must have developed an inclusory construction independently from other Mande languages.

Figure 2 summarizes the proposed logical development of inclusory constructions in Mande languages. It is not aimed at an absolute accuracy in terms of timing, this is why the emergence of inclusory construction in proto-South-West Mande and in present-day Gban, Kla-Dan and Guro appears at the same level, although proto-South-West Mande most likely had its inclusory construction much earlier.

Figure 2: Development of inclusory constructions in Mande

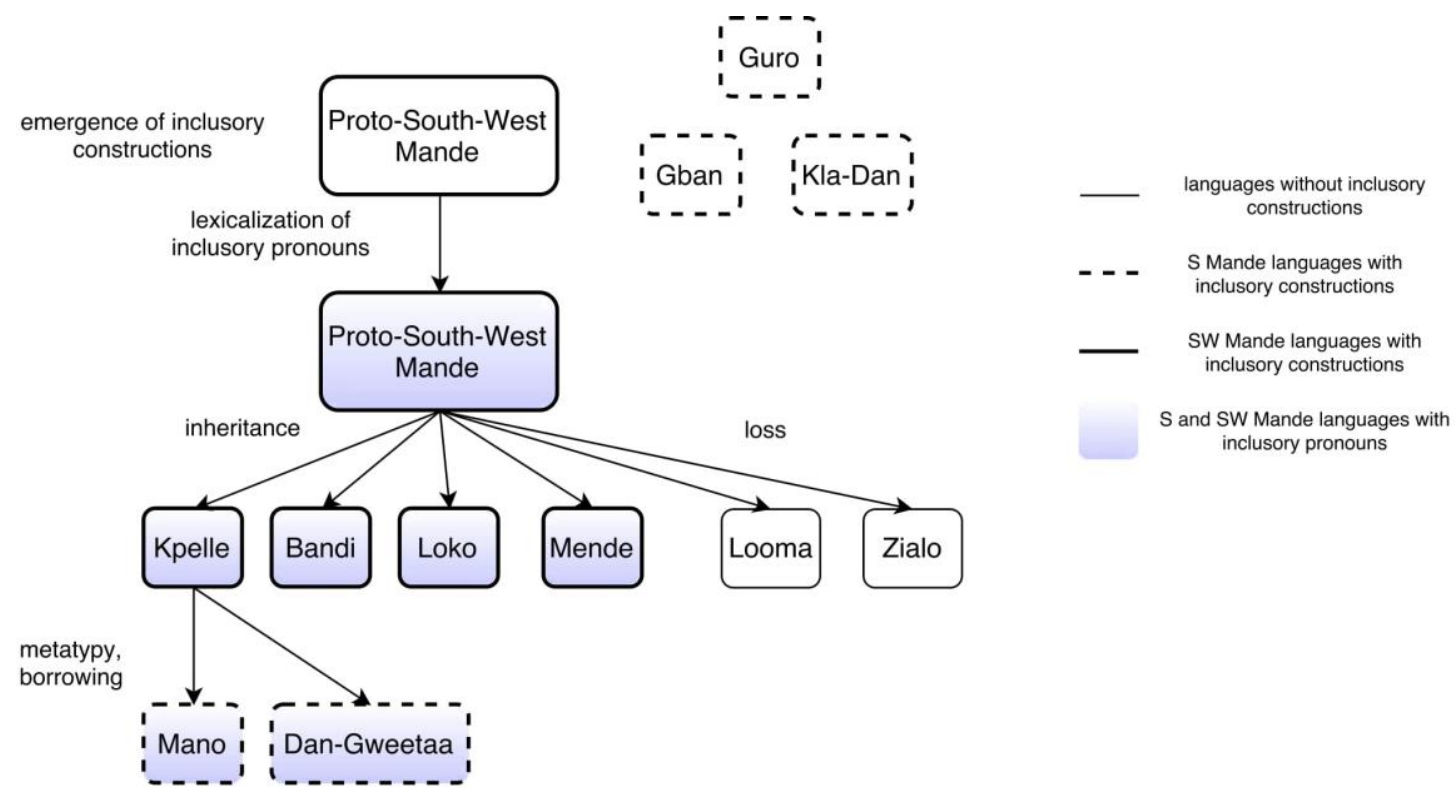

\section{Conclusion}

Inclusory constructions are a relatively widespread conjunction strategy. They are most common (and best described) in Austronesian languages, but also occur in IndoEuropean languages, including Slavic and Romance. Their distinctive feature is that one 
of its constituents, typically, a pronominal, has the same reference as the entire construction.

In this paper, I demonstrated that two distinct subgroups of Mande languages feature inclusory constructions, namely, South and South-West Mande. The most exciting fact about Mande is that in the majority of languages with inclusory constructions the inclusory pronouns are represented by a dedicated series which is used nowhere outside the inclusory construction. Mande languages seem to be unique in that respect. As I argued in this paper, this typological rarity can be explained if we take into account diachronic evidence.

Following a prior hypothesis advanced by Vydrin (2010) and Babaev (2010) and relying on typological and formal evidence, I suggested a new diachronic origin of inclusory constructions and inclusory pronouns. I argued that the inclusory construction emerged at the level of the proto-language of the South-West branch of Mande. This construction featured a non-dedicated pronoun, most probably of the focalized series, used in the inclusory function, as well as a comitative preposition. Consequently the pronoun in the inclusory function merged with the comitative preposition, and this merger gave rise to a lexicalization of a dedicated series of inclusory pronouns. Inclusory pronouns were inherited in four of the languages of the branch, namely, Kpelle, Bandi, Mende, and Loko, and were lost in Zialo and Looma.

Mano and Dan-Gweetaa, both South Mande languages featuring dedicated inclusory series, developed an inclusory construction, most probably, through contact with Kpelle. The construction could arise through metatypy, while the pronominal series was borrowed.

In three other South Mande languages, Gban, Guro and Kla-Dan, inclusory constructions grammaticalized independently, but these languages did not develop a dedicated inclusory series.

To sum up, it can be argued that inclusory constructions in Mande, which seem to follow more or less the same pattern, have in reality at least four independent sources. Inclusory constructions in six Mande languages originate, in one way or another, from proto-South-West Mande, while in Gban, Guro and Kla-Dan they grammaticalized independently. These constructions, as we observe them in the present-day languages, 
result from five different processes: grammaticalization of a construction, as in protoSouth-West Mande, Gban, Guro and Kla-Dan, lexicalization, as in proto-South-West Mande, inheritance, as in Kpelle, Mende, Bandi, Loko, and, finally, borrowing and metatypy, as in Mano and Dan-Gweetaa.

This paper introduces a typologically rare phenomenon, dedicated series of inclusory pronouns, and argues that the origin of these pronouns has nothing crosslinguistically unusual in itself. Remarkably, inclusory pronouns in South and South-West Mande are part of already very rich pronominal paradigms. Therefore, the existence of dedicated inclusory pronouns, although uncommon typologically, appears quite natural from the language-internal point of view. Thus, Mande data shows that a typological rarum appears as a result of a diachronic development following a common diachronic mechanism in the context that makes such a development favorable. The fact that the development of a typological rarum can ultimately be traced back to a typologically common source supports the view advocated by Cristofaro who argues that "When trying to account for individual patterns [...] the question should be not so much whether the pattern in itself reflects some particular principle, but rather what processes and source constructions are involved in the development of the pattern, what the motivations are for individual processes, and whether some processes or source constructions are more frequent than others" (Cristofaro 2015:13).

\section{References}

Aissen, J. (1989). Agreement controllers and Tzotzil comitatives. Language 65(3), 518536.

Arkhipov, A. (2009). Comitative as a cross-linguistically valid category. In P. Epps and A. Arkhipov (Eds.), New Challenges in Typology. Transcending the Borders and Refining the Distinctions, pp. 223-246. Berlin: Mouton de Gruyter.

Babaev, K. (2010). Person marking in South-West Mande languages: a tentative reconstruction. Mandenkan 46, 3-48.

Bauer, W. (1993). Maori. Descriptive Grammars. London: Routledge.

Beam de Azcona, R. G. (2006). A Zapotec contribution towards the typology of inclusory constructions. Paper presented at the Annual Meeting of the Society for the 
Study of the Indigenous Languages of the Americas. Albuquerque, NM, 5-8 January 2006.

Bril, I. (2004). Coordination strategies and inclusory constructions in New Caledonian and other Oceanic languages. In M. Haspelmath (Ed.), Coordinating constructions, pp. 499-536. Amsterdam: John Benjamins.

Creissels, D. (2009). Malinké de Kita : Un parler mandingue de l'ouest du Mali. Cologne: Rüdiger Köppe.

Cristofaro, S. (2015). Towards a source oriented typology. Handout presented at the Historical Linguistics and Typology conference, Austin, 12/9/2015.

Daniel, M. (2000). Tipologija assotsiativnoj množestvennosti (Typology of associative plurality). Ph. D. thesis, Moscow State University.

Drinka, B. (2017). Language contact in Europe. The periphrastic perfect through history. Cambridge: Cambridge University Press.

Fedotov, M. (2013). Glagolnyje kategorii jazyka gban [Verbal categories of the Gban language]. Master's thesis, Saint Petersburg State University.

Fedotov, M. (2016). Jazyk gban [The Gban language]. In V. Vydrin (Ed.), Jazyki mira. Jazyki mande [Languages of the world. Mande languages], pp. 902-999. Saint Petersburg: Nestor-Istorija.

Hachaturyan, M. (2010). The syntactic approach to pronominal systems in South and South-Western Mande languages. In Abstracts and papers of the International Workshop on Personal Pronouns in Niger-Congo Languages, pp. 42-47.

Haspelmath, M. (2004). Coordinating constructions: an overview. In M. Haspelmath (Ed.), Coordinating constructions, pp. 3-39. Amsterdam: John Benjamins.

Haspelmath, M. (2007). Coordination. In T. Shopen (Ed.), Language typology and syntactic description, Volume II, pp. 1-51. Cambridge: Cambridge University Press.

Hoffmann, C. (1963). A Grammar of the Margi Language. London: Oxford University Press.

Hyman, L. M. (1979). Phonology and noun structure. In L. M. Hyman (Ed.), Aghem grammatical structure, pp. 1-72. Los Angeles: University of South California Press.

Innes, G. (1967). A Practical Introduction to Mende. London: School of Oriental and African Studies. 
Konoshenko, M. (2014). Studying tonal complexity, with a special reference to Mande languages. Language documentation and preservation 8, 563-586.

Konoshenko, M. (2015). Lično-čislovoje soglasovanije $v$ jazykah mande: vnutrigenetičeskaja tipologija [Person and number agreement in Mande languages: an intralinguistic typology]. Ph. D. thesis, Institute of Linguistics, Russian Academy of Sciences.

Konoshenko, M. (2016). Kpelle jazyk [The Kpelle language]. In V. Vydrin (Ed.), Jazyki mira. Jazyki mande [Languages of the world. Mande languages], pp. 284-343. Saint Petersburg: Nestor-Istorija.

Kuznetsova, O. (2013). Glagol v jazyke guro [The verb in the Guro language]. Ph. D. thesis, Russian Academy of Sciences.

Lee, A. P.-j. (2011). Comitative and coordinate constructions in Truku Seediq. Language and linguistics 12(1), 49-75.

Lichtenberk, F. (2000). Inclusory pronominals. Oceanic Linguistics 39, 1-32.

Makeeva, N. (2012). Grammatičeskij stroj jazyka kla-dan v tipologičeskom kontekste rodstvennyh jazykov [The grammatical structure of the Kla-Dan language in a typological context of genetically related languages]. Ph. D. thesis, Institute of linguistics, Russian Academy of Sciences.

Migeod, F. (1908). The Mende Language. London: Kegan Paul, Trench, Trubner \& Co.

Mischenko, D. (2016). Jazyk looma [The Looma language]. In V. Vydrin (Ed.), Jazyki mira. Jazyki mande [Languages of the world. Mande languages], pp. 343-414. Saint Petersburg: Nestor-Istorija.

Paperno, D. (2014). Grammatical sketch of Beng. Mandenkan 51, 1-130.

Schachter, P. and F. T. Otanes (1972). Tagalog Reference Grammar. Berkeley: University of California Press.

Schwartz, L. (1985). Plural pronouns, coordination and inclusion. In N. Stetson (Ed.), Proceedings of the Tenth Annual Minnesota Conference on Language and Linguistics, Minneapolis, pp. 152-184. University of Minnesota Press.

Schwartz, L. (1988a). Asymmetric feature distributions in pronominal 'coordinations'. In M. Barlow and C. A. Ferguson (Eds.), Agreement in Natural Language, pp. 237 49. Palo Alto: CSLI. 
Schwartz, L. (1988b). Conditions for verb-coded coordinations. In M. Hammond, E. A. Moravcsik, and J. J. Wirth (Eds.), Studies in syntactic typology, pp. 53-73. Amsterdam: John Benjamins.

Singer, R. (2001). The Inclusory Construction in Australian languages. University of Melbourne Honorary Thesis.

Tesnière, L. (1951). Le duel sylleptique en français et en slave. Bulletin de la Société de Linguistique de Paris 47, 57-63.

Thomason, S. G. (2001). Language contact. An introduction. Washington: Georgetown University Press.

Vydrin, V. (2006). Ličnyje mestoimenija v južnyh jazykah mande [Personal pronouns in South Mande]. Transactions of the Institute of linguistic studies II(2), 333-419.

Vydrin, V. (2009). On the problem of the Proto-Mande homeland. Journal of Language Relationship 1, 107-142.

Vydrin, V. (2010). Co-ordinative pronouns in South and South-West mande: A second compound pronouns area in Africa? In V. V. Konstantin Pozdniakov and A. Zheltov (Eds.), Personal pronouns in Niger-Congo languages: International workshop, 1315 September 2010, pp. 164-172. St. Petersburg University Press.

Vydrin, V. and M. Morozova (2016). Jazyk loko [The Loko language]. In V. Vydrin (Ed.), Jazyki mira. Jazyki mande [Languages of the world. Mande languages], pp. 414-456. Saint Petersburg: Nestor-Istorija.

Vydrine, V., T. Bergman, and M. Benjamin (2000). Mandé language family of West Africa: Location and genetic classification. SIL Electronic Survey Reports 2000-003. Available at: http://www.sil.org/silesr/2000/2000-003/silesr2000003.htm.

\begin{tabular}{llll}
\multicolumn{4}{l}{ Abbreviations (not included in Leipzig Glossing Rules) } \\
AOR & aorist & JNT & joint \\
ASSOC & associative & L & low tone \\
AUT & automonous & NP & noun phrase \\
BAS & basic & P.N. & proper noun \\
CNTR & contrastive & POS & positive
\end{tabular}




$\begin{array}{llll}\text { CONJ } & \text { conjunctive } & \text { POSTP } & \text { postposition } \\ \text { COORD } & \text { coordinative } & \text { PP } & \text { postpositional/prepositional phrase } \\ \text { EMPH } & \text { emphatic } & \text { PREP } & \text { preposition } \\ \text { EXI } & \text { existential } & \text { PROSP } & \text { prospective } \\ \text { H } & \text { high tone } & \text { QUAL } & \text { qualitative } \\ \text { HAB } & \text { habitual } & \text { REF } & \text { referential } \\ \text { HOD } & \text { hodiernal } & & \end{array}$

\section{Appendices}

Table i: Tonal marking in Mande examples

Name of the tone 2-level systems3-level systems4-level systems5-level

\begin{tabular}{|c|c|c|}
\hline (Maninka) & $\begin{array}{l}\text { (Mano, } \\
\text { Guro) }\end{array}$ & (Kla-Dan) \\
\hline
\end{tabular}

Gweetaa)

Ultrahigh ä ä

High á á á á a a a a a a

Mid $\overline{\mathrm{a}} \quad \overline{\mathrm{a}}$

Low à $\quad$ à $\quad$ à $\quad$ à

Table ii: Personal pronouns, affixes and auxiliaries in Kpelle

\begin{tabular}{|c|c|c|c|c|c|c|c|}
\hline & $1 \mathrm{SG}$ & $2 \mathrm{SG}$ & $3 \mathrm{SG}$ & 1PL.INCL & 1PL.EXCL & 2PL & 3PL \\
\hline \multicolumn{8}{|c|}{ Personal pronouns } \\
\hline Autonomous & & $y \varepsilon ́$ & $y \check{a} \sim y \grave{a} a ̆$ & gùó & kúó & káá & dié \\
\hline Topic-1 & ýwći & éwčí & $\grave{y} w \varepsilon ̌ i$ & ǧ̌wě̀ & kúwěl & káwěl & dǐwěl \\
\hline Topic-2 & nááý & yéń & yàáý & gùóń & kúóý & kááń & diéý \\
\hline Possessive & y’́ yá yé & éwó & $\eta \grave{\jmath} \sim \eta \grave{a}$ & gùwó & kúwó & káwó & dìwó \\
\hline Inclusory & - & - & - & gwà & $k w a ̀ ~$ & kà & $d \grave{a}$ \\
\hline Citational & $g \hat{\varepsilon}$ & $y \hat{\varepsilon}$ & $y \grave{\varepsilon}$ & gùò & kúô & káà & dì̀ \\
\hline \multicolumn{8}{|l|}{ Auxiliaries } \\
\hline
\end{tabular}


